\title{
NEW WAYS OF LOOKING INTO HANDWRITTEN MISCELLANIES OF THE SEVENTEENTH CENTURY: THE CASE OF SPES ALTERA
}

\author{
Purificación Ribes Traver \\ Universitat de València \\ purificacion.ribes@uv.es
}

\begin{abstract}
A large number of copies of Shakespeare's Sonnet 2 circulated in handwritten miscellanies from the second quarter of the Seventeenth Century. Eleven of those copies have significant variant readings that have led critics to put forward different hypotheses regarding their nature and quality. Most critics, taking into account stylometric analyses, have regarded them as early drafts of Shakespeare's printed version, and have agreed on their poor quality.

By paying due attention to the text's context of production and reception, we have reached a different conclusion regarding both the nature and quality of the handwritten versions of Sonnet 2. In our view, they are the product of a conscious rewriting on the part of some educated member of the universities or Inns of Court. Close reading of the manuscript copy text (Spes Altera, Bellasys Ms, c.1630), and a line by line comparison with the $1609 Q$ text, suggest a deliberate attempt on the part of its adapter at increasing the poem's metrical regularity and structural coherence.
\end{abstract}

Keywords: Rewriting, Spes Altera, 1630, handwritten miscellanies, Shakespeare Sonnet 2, 1609 Quarto. 


\title{
NUEVA APROXIMACIÓN A LOS VOLÚMENES MISCELÁNEOS MANUSCRITOS DEL SIGLO XVII: EL CASO DE SPES ALTERA
}

\begin{abstract}
RESUMEN. Numerosas copias del Soneto 2 de W. Shakespeare circularon en volúmenes misceláneos manuscritos del segundo cuarto del Siglo XVII. Once de esas copias presentan variantes importantes, que han dado lugar a diferentes hipótesis respecto a su naturaleza y calidad. La mayoría de los críticos, partiendo de análisis estilométricos, las han considerado como bocetos tempranos de la versión impresa posterior, y, en consecuencia, les han atribuido un escaso valor.

En este trabajo se presta la atención necesaria al contexto de producción y recepción de estos textos, lo que ha permitido alcanzar conclusiones distintas respecto a la naturaleza y calidad de las versiones manuscritas del Soneto 2. Opinamos que son el fruto de una reescritura consciente por parte de una persona culta perteneciente a un entorno universitario. El análisis pormenorizado del texto base (Spes Altera, Bellasys Ms, c. 1630), y una comparación verso a verso entre este texto y el Quarto impreso en 1609, ponen de relieve una intención deliberada, por parte del adaptador, de incrementar la regularidad métrica y la coherencia estructural del poema.
\end{abstract}

Palabras clave: Reescritura, Spes Altera, 1630, volúmenes misceláneos manuscritos, Soneto 2 de W. Shakespeare, edición en Quarto de 1609.

Received 18 September 2019

Revised version accepted 30 September 2020

\section{INTRODUCTION}

Our approach to the study of the handwritten version of Shakespeare's Sonnet 2 follows Arthur F. Marotti's guidelines, as put forward in his Circulation of Verse at the Inns of Court and in London in Early Stuart England (2016b), "Historical evidence, textual analysis, literary interpretation, and cautious conjecture need to be combined in order to lead to a greater understanding of individual texts, compilations of texts, and their contexts" (64).

This is exactly what we have done when assessing both the nature and quality of the handwritten versions of Sonnet 2 as contained in manuscript miscellanies from the second quarter of the Seventeenth Century. Having collated the eleven texts with substantial variant readings, we have chosen the version contained in Margaret Bellasys' miscellany, dated c. 1630, on account of its accuracy. ${ }^{1}$

1 Following Taylor (1985), most editors have chosen the Westminster Manuscript as their copy text taking into account its closeness to the first printed edition of the poem. See Wells, Taylor, Jowett and Montgomery (1987/1997: 444, 445 and 447); Kerrigan (1986/1999: 449-450); Blakemore Evans (1996/2006: 268-269); Greenblatt, Cohen, Howard \& Eisaman Maus (1997: 1985); Burrow (2002: 691); Taylor, Jowett, Bourus and Egan (2017, vol 1: 438). In our view, the text contained in the Bellasys manuscript should be preferred as a control text in view of its greater accuracy. 
NEW WAYS OF LOOKING INTO HANDWRITTEN MISCELLANIES OF THE SEVENTEENTH CENTURY...

We have next paid close attention to the text's context of production and reception, as it is essential in order to understand the capacities, attitude, and approach of compilers to the texts included in their miscellanies. Even though the exact identity of the compiler of the Bellasys miscellany cannot be ascertained, attention to the texts in the miscellany reveal that he was educated and must have taken pride in rewriting the texts of authors as relevant as John Donne. As a matter of fact, the miscellany includes eight of his poems, substantially rewritten according to the adapter's personal taste. A.L. Crowley (2018) draws attention to the extent to which these poems have been rewritten (173-211), as well as to the consistency of their pattern of re-envisioning (179). She concludes, "these supposedly corrupt texts (very corrupt indeed by traditional editorial standards) provide evidence of a sensitive literary mind at work with Donne's poems" (181) This is precisely the conclusion we have reached after analysing the handwritten version of Sonnet 2 here titled Spes Altera - and comparing it to the 1609 printed version of the poem.

We agree with Schoenfeldt (2007) on the "chronic inscrutability of Shakespeare's Sonnets" (125), and with Burrow's (2007) view that "the sonnets invite close inward attention" (145). That is why we have paid close attention both to the 1609 printed version of Shakespeare's Sonnet 2 and to the 1630 manuscript version of Spes Altera. Our conclusion, however, widely differs from that reached by Roberts (2003) when she says, "the claims made in modern criticism for the daring originality, singularity, unconventionality and unorthodox brilliance of Shakespeare's Sonnets stands at odds with the transmission and reception of the Sonnets in print and manuscript in early modern England" (2003: 189). We assume this conclusion stems from her previous contention that Spes Altera "reads as a conventional love poem" (180), an instance of a carpe diem lyric addressed to a female beloved (177). Close attention to the poem, however, makes that conclusion difficult to sustain, as Spes Altera (A Second Hope) can have both a male and a female addressee. Besides, it is not common for a carpe diem poem to persuade its addressee to have children. Its aim is rather that of taking advantage of the present time by enjoying it to the full. The content of Spes Altera, however, can be easily related to Erasmus's Encomium matrimonii, a letter addressed to a bachelor who was reluctant to marry, and which was translated into English by Thomas Wilson, and included in his popular Arte of Rhetorique.

Finally, as Marotti has pointed out, "well educated, socially sophisticated, politically aware gentlemen carried over from their youthful university years into their later careers a taste for witty verse and prose" (2016a: 875). This is precisely the conclusion O'Callaghan (2006) reaches when analyzing the different versions of "The Parliament Fart" in manuscript miscellanies from the period. Although he recalls the political significance of the incident it refers to -that of the Union of the kingdoms under James I, whose defence at Parliament by Sir John Croke was interrupted by H. Ludlow's fart- 
he highlights the fact that the poem, also included in the Bellasys miscellany, was read "as much for its humour as for its politics" (133). O'Callaghan's conclusion resembles that of Marotti, as he claims that "jesting, including licentious raillery, was perceived to be an appropriate mode of recreation for the cultivated gentleman. The witty jest was a cultural marker of his civility and of membership in an exclusive social group" (2006: 134). This, in our opinion, is the context which gave rise to the 1630 rewriting of Shakespeare's Sonnet 2, which, far from looking like the outcome of inattentive copying on the part of a scribe (Duncan Jones 1997: 456), has signs of deliberate rewriting aimed at achieving greater metrical regularity and structural coherence. In the pages that follow, the texts of $1609 \mathrm{Q}$ and 1630 Bellasys MS are transcribed, followed by a collation of their variant readings, a line by line comparison between $\mathrm{Q}$ and $\mathrm{MS}$, and an assessment of their differences in the light of their respective contexts of production and reception.

\section{1609 QUARTO AND 1630 BELLASYS MS}

\subsection{QUARTO TEXT}

\section{2}

WHen fortie Winters $\int$ hall be eige thy brow,

And digge deep trenches in thy beauties field,

Thy youthes proud liuery fo gaz'd on now,

Wil be a totter'd weed of $\int$ mal worth held:

Then being askt, where all thy beautie lies,

Where all the treafure of thy lufty daies;

To fay within thine owne deepe funken eyes,

Were an all-eating Shame, and thriftle $\iint \mathrm{e}$ praife.

How much more praife deferu'd thy beauties vfe,

If thou could $\int \mathrm{t}$ anfwere this faire child of mine

Shall fum my count, and make my old excufe

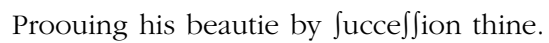

This were to be new made when thou art ould,

And Jee thy blood warme when thou feel'st it could, 


\subsection{BELLASYS MS TEXT}

(British Library, Add. MS 10309, f. 143r, c. 1630. [B1])

$$
\text { Spes Altera }
$$

When thre core winters $\int$ hall be eige thy brow

And trench deepe furrowes in $\mathrm{y}^{\mathrm{t}}$ louely feild

Thy youths faire Liu'rie Joe accounted now

Shall be like rotten weeds, of no worth held.

Then being afk'd where all thy beautie lies

Where's all ye Luftre of thy youthfull dayes

To fay $\mathrm{w}^{\mathrm{TH}}$ in the $\int \mathrm{e}$ hollow- $\int$ unken eies,

Were an all-eaten truth, \& worthle $\iint e$ praife.

O how much better were thy beauties ufe

If thou could ft fay, this pretty childe of mine

Jaues my account, \& makes my old 'excule

Making his beautie by $\int u c c e \iint$ ion thine.

This were to be new borne, when $\mathrm{y}^{\mathrm{U}}$ art old

And $\int e e$ thy blood warme, when $\mathrm{y}^{\mathrm{U}}$ feel' $\int \mathrm{t}$ it cold.

\section{COLLATION OF Q AND THE MANUSCRIPT VERSIONS ${ }^{2}$}

For this section we draw on Taylor's (1985: 211; 1987/1997: 447) and Blakemore Evans' (1996: 268-269) collations. B1+ indicates that all the MSS. agree with B1 unless otherwise noted.

Title 2] Q; Spes Altera] B1, B2, B3; Spes Altera A song F3; To one $\mathrm{y}^{\mathrm{t}}$ would dye a Mayd B4, B5, F2, W, Y; A Lover to his Miftres N; The Benefitt of Mariage R

1. fortie] Q; threfcore] B1; fortie W, B1, B2, B3, B4, B5, F2, F3, Y, R

1. Winters] Q, B1+; yeares $\mathrm{R}$

2 List of witnesses according to Beal (1980: 452-453), followed by Taylor's sigla (1985: 211; Wells and Taylor 1987/1997: 444), and the dates he provides for them (2017: 437). 
2. digge] Q; trench $\mathrm{B} 1+$; drench $\mathrm{R}$

2. trenches] Q; furrowes B1+

2. thy beauties field] Q; $\mathrm{y}^{\mathrm{t}}$ louely feild, B1+; cheeke B2, B3

3. youthes] Q, B1+; youth B5, F3

3. proud] Q; faire $\mathrm{B} 1+$; fairer $\mathrm{R}$

3. liuery] Q; Liu'rie B1; liuerie B2, B3, B4, B5, F2, F3, N, W; field R

3. gaz'd on] Q; accounted B1+; accompted B3; e fteemed N

4. Wil be a totter'd weed of smal] Q; Shall bee like rotten weeds of no B1+; Shall be like like rotten weeds of no B5; Shall bee like rotten cloaths of no F2

5. being askt] Q; being a $\int k$ 'd B1+; if we A $\int k$ B2; if wee aske B3; a $\int k t ~ R$

5. thy] Q, B1+; this B3

5. lies] Q, B1, B5, F2, Y; lyes B2, B3, B4, F3, R; lye W (cropped)

6. Where] Q; Where's] B1, B2, B3, F3, N, R; Where W

6. treafure of thy lusty] Q; Luftre of thy youthfull B1+

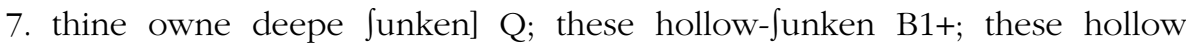
Juncken W; thofe hollow-sunken Y; hollow-sunken B4

8. all-eating fhame, and thriftle $\left.\iint \mathrm{e}\right] \mathrm{Q}$; all-eaten truth, \& worthle $\iint \mathrm{e} \mathrm{B} 1+$; allbeaten truth, \& worthlesse F2

8. praife] Q; prayfe B1+; prayf W (cropped); prayes B4; pleafure B5

9. How much more praife deferu'd] Q; O how much better were B1+; how much better were $\mathrm{B} 5$; O whow much better were $\mathrm{B} 4$; O how far better were $\mathrm{Y}$; how better were B5

9. beauties] Q, B1+; bewtious Y

ShW 8, British Library, Add. MS 10309, f. 143r, c. 1630. (B1)

ShW 9, British Library, Add. MS 21433, f. 114v, c. 1630s. (B2)

ShW 10, British Library, Add. MS 25303, f. 119v, c. 1620s. (B3)

ShW 11, British Library, Add. MS 30982, f. 18r, c. 1631-3. (B4)

ShW 12, British Library, Sloane MS 1792, f. 45r, c.1630s. (B5)

ShW 13, Folger, MS V. a. 170, pp. 163-4, c. 1630-55. (F2)

ShW 14, Folger, MS V. a. 345 , p. 145 , c. 1620 s. (F3)

ShW 15, University of Nottingham, Portland MS Pw V 37, p. 169, c. 1630. (N)

ShW 16, Rosenbach Foundation, MS 1083/17, ff. 132v-133r, c. 1638-42. (R)

ShW 18, Westminster Abbey, MS 4, f. 49r, c. 1620s-40s. (W)

ShW 19, Yale, Osborn Collection, MS b 205, f. 54v, 1623-35. (Y) 
NEW WAYS OF LOOKING INTO HANDWRITTEN MISCELLANIES OF THE SEVENTEENTH CENTURY..

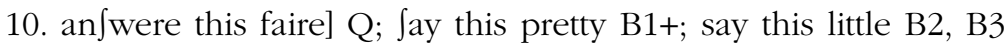

11. Shall Jum my count] Q; Jaues my account B1+; Saud my account Y; saues mine account $\mathrm{N}$; saues my accompt B3

11. make my old] Q; makes my old] B1, B2, B3, B5, F3, W, makes me old B4; makes no old F2; yeilds mee an $\mathrm{N}$; makes the old $\mathrm{R}$; make no old $\mathrm{Y}$

13. new made] Q; new borne B1+; made younge B2, B3

14. feel' $\left.\int \mathrm{t}\right] \mathrm{Q}, \mathrm{B} 1+$; fel $\int \mathrm{t} \mathrm{B} 2, \mathrm{~B} 3, \mathrm{~B} 4$

\section{LINE BY LINE COMPARISON BETWEEN Q AND B1}

The following section consists of a line by line comparison between $\mathrm{Q}$ and B1, in order to assess their differences in terms of poetic structure, imagery, rhythm and style. The MS text precedes the Q text.

Title: Spes Altera (MS) This added heading is typical of the educated milieu where the manuscript was presumably compiled, and where, as Marotti points out, "authors lost control of their texts and others felt free to transcribe, alter, and arrange them as they saw fit" (2007: 185).

\subsection{When thre fcore winters Shall be feige thy brow, \\ WHen fortie Winters Shall be feige thy brow,}

"Thre $\int$ core" is interchangeable with "fortie" in terms of rhythm. It means "three times twenty; sixty" (OED adj. a), and makes the idea of devastating old age clear, as the youth does not have to add forty years to his age.

"Thre core" followed by "ten" appears in Psalm 89 in a context that, like Sonnet 2, reminds the reader of the brevity of his life: "The dayes of our age are iij. score yeares \& ten [...] so soone passeth it awaye, \& we are gone". The passage concludes with a message comparable to that of the Sonnet: "O teach vs to nombre our dayes, that we maye applie oure hertes vnto wyßdome".

Sonnet 2, like Psalm 89, later illustrates the passage of time through an image related to the field of nature. The Psalm's "they [...] fade awaye sodenly like the grasse. [...] In the mornynge it is grene and groweth vp, but in the euenynge it is cutt doune and wythered" can be related to the Sonnet's "lovely field" that ends up as "rotten weeds". 3

\footnotetext{
3 The sonnet's biblical overtones recur at other points in the sonnet, especially in 11. 10-11, that read "[...] this pretty child of mine / Saues my account", which can be easily related to man's final reckoning at the judgement seat of God.
} 
PURIFICACIÓN RIBES TRAVER

\section{l.2. And trench deepe furrowes in $y^{\mathrm{t}}$ louely feild}

And digge deep trenches in thy beauties field,

This line shows the compiler's attention to sound, as "trench deepe furrowes" reads better than "digge deep trenches", and the repeated lateral sound "l" in " $\mathrm{y}^{\mathrm{t}}$ louely field" sounds smoother than the "plosive "b" in "beauties field".

The use of the deictic "that" in " $\mathrm{y}^{\mathrm{t}}$ louely field", moreover, makes the line's tone more dramatic and direct than the variant in $Q$.

\subsection{Thy youths faire Liu'rie Soe accounted now}

Thy youthes proud liuery Jo gaz'd on now,

Q "proud" highlights the youth's awareness of the admiration he draws from those around him, whereas "faire" continues the tone started in line 2 with "louely" [field].

Q "Gaz'd on" fits in with the idea of a proud livery drawing the admiration of onlookers, whereas "Joe accounted now" anticipates the sonnet's changed perception of the addressee in the future, and highlights the contrast between the present time, when everybody agrees that he is good-looking, and the future, when his sunken eyes will lead to a different perception of his looks.

The MS's use of the syncopated form "Liu'rie" makes the stress fall on "Joe", thereby highlighting the contrast between the current appraisal of his "faire Liu'rie" ("Soe accounted now") and the world's future opinion of it: "of no worth held".

If we take into account the polysemic nature of "Liu'rie" and "faire", the meaning of "thy youths faire Liu'rie" could be extended beyond the idea of the youth's beautiful appearance, and include that of God's substantial allowance which the youth is expected to put to good use, as he will later have to account for it. "Fair" (OED A. adj. I.1.) "Beautiful to the eye; of attractive appearance; good-looking"; (A.adj. I.5.) "Of amount or extent: great, considerable, generous, large in size or amount"; "Livery" (OED II.) "Senses relating to clothing or other uniform which serves as a distinguishing characteristic"; (III.8.a.) "The food, provision or clothing dispensed to or supplied to retainers, servants, or others; an allowance or ration of food served out". The second meaning is exemplified by T. Brooks Wks VI.47 (1670) "They serve God for a livery, for loaves, and not for love".

\subsection{Shall be like rotten weeds, of no worth held.}

Wil be a totter'd weed of Jmal worth held: 
The impression that the youth's livery is going to lose all its beauty and lustre is made clearer in MS, as "no" is stronger than "Smal", its force being highlighted by the fact that no final consonant limits the possibility of lengthening its vowel sound when emphasized by a speaker. Conversely, "Smal" has a short vowel which is followed by a consonant sound, and cannot be lengthened.

The adjective "rotten", that precedes "weeds" in MS, is more forceful than "totter'd". Besides, it further develops the idea of the young man's face as a beautiful field that will rot and cease to be fruitful unless cultivated. "Weeds" in the plural points to the agricultural image in the first place, and only then to the idea that the youth's beauty is his livery, that may wear away with the passage of time. In Q, "a totter'd weed" has not lost its value completely because it still covers his body, unlike the rotten weeds that signify barrenness.

\section{ll. 5-6. Then being a fk'd where all thy beautie lies}

Where's all $y^{\mathrm{e}}$ Lu Stre of thy youthfull dayes

Then being askt, where all thy beautie lies,

Where all the trea Sure of thy lu fty daies;

MS "Luftre" follows from "beautie" in the preceding line. The passage of time is made explicit again by relating "Luftre" to the man's "youthfull dayes", which will then be over. It must be noted that "Luftre", apart from meaning "splendour of countenaunce" (OED n.3) has the additional figurative meaning of "splendour of renown; glory" (OED n.4.a.). It is also associated with the idea of bright eyes, as in Shakespeare's King Lear, where Cornwall, while removing Gloucester's eyes, constrasts their past lustre with their present hollowness, "Lest it see more, prevent it. Out, vile jelly! Where is thy lustre now?" (III.vii.85-86).

Q "treasure" and "lusty" are polysemic words and may hint at the youth's sexual activity, or may be limited to the value of the time when he was full of energy and beauty.

"Where's" in MS may be considered a grammatical mistake, as it seems to ignore the rules of reported speech. It might, however, be intentional, in line with the direct tone of the sonnet.

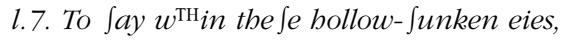

To say within thine owne deepe Junken eyes, 
Again the MS version reads better and has a more dramatic tone than Q. MS replaces "thine owne" with the deictic "the e", far more effective when the addressee points to his hollow eyes. It has the additional advantage of being shorter, which

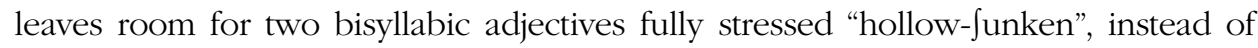
Q's "deepe Junken", where the first adjective only receives a secondary stress.

l.8. Were an all-eaten truth, \& worthle $\int e$ prai $\int e$.

Were an all-eating Shame, and thriftle $\int e$ prai $\int e$.

MS "all-eaten truth" is a hollow truth, because it contains nothing. It is as hollow as the man's eyes, now the reflection of approaching death. If someone says his youthful beauty lies in his sunken eyes, his answer makes no sense, as it does not provide a satisfactory justification for his niggardly behaviour. The image echoes its meaning: the truth is as empty and full of holes as an all-eaten trunk or a pumeise stone. "Eat", (OED II) "To destroy by devouring"; (10. transf. a.) "Of slow and gradual action, as of frost, rust, cancerous or similar disease, chemical corrosives, the waves, etc.". Some recent editors, however, offer an interpretation of "all-eaten" that is difficult to sustain in the context of the line. Thus, according to Greenblatt (1997: 1985) "an all-eaten truth" is "an accurate statement that you had been gluttonous".

Q "all-eating shame" is an "all-devouring shame". "Eating" (OED, adj.1.a.) "That eats, chiefly in combination with prefixed object. Formerly also greedy, voracious". It has been fittingly paraphrased by Bate and Rasmussen (2007: 2435) as "gluttonous shame that totally consumes you". Other editors, however, offer less convincing explanations. Thus, Greenblatt (1997: 1924) and Taylor, Jowett, Bourus and Egan (2016: 2820) explain "an all-eating shame" as "a shameful admission of gluttony".

MS "worthle $\iint e$ praife" is in line with the clear and forceful tone of the line, and verbally echoes "no worth" in line 4.

Q "thriftle $\iint e$ " is interchangeable with "worthle $\iint e$ " in terms of meaning (OED, adj. 2) "Unprofitable, worthless, useless", as in Shakespeare's Twelfth Night (1623) II.ii.39 "what thriftlesse sighes shall poore Olivia breath?" or M.Fotherby's Atheomastix (1622) I.vi.4.47, "the most thriftless and vnprofitable part of all the whole tree". Some recent editors, however, have pointed out additional meanings, which make little sense in this context. Thus, Kerrigan suggests the possibility of reading "thriftle $\iint e$ praife" as "praise for your wasteful profitableness" (1986: 449), an interpretation similar to that of Greenblatt, who explains it as "a boast of excessive expenditure" (1997 [1986], 1924), or Taylor, Jowett, Bourus, and Egan (2016: 2820), who paraphrase it as "a boast of extravagance".

4 A marginal note to J. Brinsley's English translation of Virgil's Eclogues, Ch. 8, explains "In the trunke of an eaten tree" as "of a tree all eaten with rotennesse" (1620: 108). 
NEW WAYS OF LOOKING INTO HANDWRITTEN MISCELLANIES OF THE SEVENTEENTH CENTURY...

\subsection{O how much better were thy beauties $u$ Se}

How much more prai $\int e$ de eru'd thy beauties vse,

Both texts are rhythmically equivalent. However, MS is more dramatic, as the exclamation "O" introduces the line. It is clearer and more direct than Q, as "to be much better" is more direct and effective than "to deserve much more praise", since what is at stake here is not so much the degree of praise the youth deserves as the awareness that beauty can be put to good use (the outcome will naturally be praiseworthy).

\section{l.10. If thou could St fay, this pretty childe of mine}

\section{If thou could St an fwere this faire child of mine}

MS reads better and emphasizes the key words in a natural way. "Say" is monosyllabic, and makes it possible for the adjective "pretty" to be stressed, thereby highlighting the father's pride in his loving child. "Pretty" is more appropriate than "faire" to refer to a child, and better conveys the father's feeling of affection for it. The second syllable of "anfwere" in Q, however, is unstressed, and, due to the line's iambic rhythm, has the negative effect of leaving "faire" unstressed and clumsily placed between "this" and "child".

\section{l.11. Saues my account, \& makes my old 'excu fe}

Shall sum my count, and make my old excu Je

The MS uses the present tense ("Jaues", "makes"), which is more forceful than the future in Q. Besides, it starts the line with an effective trochaic inversion (fáues my) that highlights the idea of the child rescuing his father from eternal damnation when answering before the Almighty for the use he has made of his gifts (beauty and youth).

Conversely, Q describes a future action by using two verbs in the future tense ("shall sum", "shall make"). The auxiliary "shall" is placed at the beginning of the line and takes up space, so that "account" must be replaced with "count", with the effect that the idea of "summing one's count" is less forceful than "saving one's account".

MS "account" has the additional advantage over "count" of its biblical overtones. In Luke xvi, 2 we read "Giue an accompt of thy stewardship". It must be noted that MS B3 has the variant "accompt" for "account", which could be explained as a wish to echo the biblical text more closely.

"Account" (OED n. III.5.) "A statement accounting for the administration of money held in trust or required by a creditor"; (III.7. I) "Christian theology: the final reckoning at the judgement seat of God". 
MS and Q offer the same reading for the second half line: "makes my old

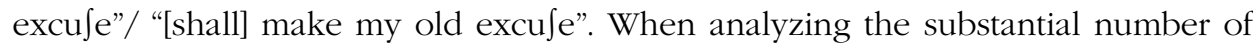
variant readings for this half line, we realized its puzzling nature, which had led most Seventeenth-century compilers to look for alternative readings that could make greater sense. As recently as 2006, Blakemore Evans, whose commentary notes are usually accurate, tried to explain this crux by saying: "the syntax encourages misreading [...] the adjective "old" is made to stand for "old age", and the noun "excuse" given a verbal force with the legal sense of declaring him innocent of the crime of wasting his youth". Blakemore Evans, accordingly, paraphrased "make my old excuse" as "justify (through offspring) my old age" (1996/2006: 111). The difficulty of making sense of these words made Burrow (2002: 384) go as far as to suggest that "make my old excuse" could be understood as "the excuse I habitually make", which makes no sense in this context.

My contention is that "old" could be understood as "clever, knowing" (OED, adj. 5, slang), as in Shakespeare's Love's Labour's Lost, II.i.254 (1598) 'thou art an old lovemonger, and speakest skilfully'. This way, we would not have to look for grammatical inconsistencies, as a "clever excuse" would make full sense in the context of the line.

\section{l.12. Making bis beautie by succe $\iint$ ion thine.}

Proouing his beautie by Jucce Jion thine.

The variant "Making" in MS echoes the verb "makes" from the previous line and underlines the idea that the boy's beauty proves an effective excuse in his old age. That connection is less marked in Q's "proouing".

\subsection{This were to be new borne, when $y^{\mathrm{U}}$ art old}

This were to be new made when thou art ould,

"New borne" in MS sharply contrasts with "old", and proves more effective than "new made". Moreover, it comes closer to the natural images of the sonnet, where the young man has been compared to a lovely, fruitful field that risked becoming barren unless put to good use.

l.14. And See thy blood warme, when $y^{\mathrm{U}}$ feel' $\int t$ it cold.

And See thy blood warme when thou feel' 't it could,

This final line extends the contrast between life and death by opposing "warm blood" to "feeling cold". It follows naturally from the previous line, where a new born was opposed to old age. 
NEW WAYS OF LOOKING INTO HANDWRITTEN MISCELLANIES OF THE SEVENTEENTH CENTURY...

In 1985, Taylor drew attention to certain verbal parallelisms between some variants in the MS versions and Thomas Wilson's translation of Erasmus's "Epistle to Persuade a Yong Iengleman to Marriage", included in his Arte of rhetorique, first published in 1553. Reflecting on the verbal closeness between "new borne"... "old age" (1. 13), and "pretty" (1. 10) in both texts, ${ }^{5}$ he put forward the hypothesis that MS could be an early draft of the Sonnet. This hypothesis was further supported by Burrow (2002), in whose view it provided the most conclusive evidence of the variants early dating: "This is the strongest argument that the poem reflects an early draft" (106).

It must be remembered, however, that The Art of Rhetoric was extremely popular and went through eight editions between 1553 and 1585 (Medine 1993: 8-9). It could be easier to think that the compilers of the manuscripts that chose these words were familiar with Wilson's translation of Erasmus's Encomium matrimonii. Besides, according to Judith R. Henderson, "Schoolmasters continued throughout the century to anthologize, abridge, and adapt Erasmus's instructions on letter writing for their use in their own classrooms" (149).

Finally, Mowat-Werstine (2004: 619-624) reproduced passages from Erasmus's Epistle without relating them to the manuscript versions of Sonnet 2, but only to some of the sonnets printed in Q, which suggests that the Sonnet's verbal closeness to passages in The Art of Rhetorique may have been introduced either before or after $\mathrm{Q}$.

\section{THE TEXTS' CONTEXTS OF PRODUCTION AND RECEPTION}

The context of production of the 1609 Quarto widely differs from that of the handwritten miscellanies presumably compiled during the second quarter of the Seventeenth century. Whereas the printed edition supplies the reader with specific information about the date of publication and the identity of the poems' author, the handwritten miscellanies seldom specify the identity of their compilers, and

5 Erasmus' Epistle, translated by Thomas Wilson, reads as follows:

Now again, what a ioye shal this be vnto you, when your moste faire wife, shall make you a father, in bringyng furthe a faire childe vnto you, where you shall haue a pretie litle boye, runnyng vp and doune youre house, suche a one as shall expresse your looke, and your wiues looke, suche a one as shall call you dad, with his swete lispyng wordes [...] You haue them that shal comforte you, in your latter daies, that shall close vp your iyes, when God shall call you, that shall bury you, and ful|fill all thynges belongyng to your Funerall, by whom you shall seme, to bee newe borne [...] Old age cometh vpon vs all, will we, or nill we, and this waie nature prouided for vs, that we should waxe yong again in our children [...] what man can be greued, that he is old, when he seeth bis awne countenau ce whiche he had beyng a childe, to appere liuely in his sonne? [...] as a yong graffe buddeth out, when the old tree is cut doune. Neither can he seme to dye, that, when God calleth hym, leaueth a yong child behinde hym (1553, fol. 31) (my italics). 
the texts they contain are predominantly unattributed. They have often been compiled over a number of years, and it is not easy to determine their exact date of composition. However, most of the manuscripts containing a handwritten transcript of Sonnet 2 date from the 1620s and the 1630s, and are associated with the universities or the Inns of Court. They typically contain texts in prose and verse of a varied nature that includes love lyrics, political and religious texts, with a surprising diversity of approaches within the same compilations. ${ }^{6}$ It is thus possible to find idyllic pastoral poems alongside bawdy epigrams, or anti-monarchic libels close to cavalier lyrics.

The text we have selected as our copy text is contained in the British Library Add. MS 10309, f.143r, a duodecimo miscellany of verse and prose made up of 155 leaves, compiled around 1630. The final page of the volume (f.155v) has a table of contents and the signature of someone called "Margrett Bellasys", whose identity has not been determined yet, even though different attempts have been made on the part of several critics. ${ }^{7}$ This far, none of them is conclusive, and their hypotheses include the possibility of connecting her with royalist and republican circles (Crowley 2018: 181). Even though some critics initially thought the handwriting of the signature was identical to that of the manuscript (Ennis 1941: 141), close attention to it rules out that possibility. The manuscript is written in a neat italic hand that looks like that of a professional scribe, who could have been commissioned by Margaret Bellasys herself, or by someone in her circle, to transcribe the text. She seems to have owned it at some point, and to have handed it down to some members of her family, who deemed it worthy of preservation, which is the reason why it has reached us. ${ }^{8}$ Different hypotheses have been put forward regarding her part in the volume, and, although some miscellanies by female compilers have been preserved, ${ }^{9}$ it is unlikely that she had an active part in the transcription of some misogynist and utterly bawdy poems in the collection such as "Comit. Somers", which immediately follows Shakespeare's Sonnet 2. Moreover, the fact that her signature follows a table of contents that does not list all the texts in the volume, but merely a few of a moralistic nature - "Characterismes of Vices" - sets her apart from certain texts in the miscellany for whose compilation she probably would not like to be held responsible. This attitude would not be surprising if one takes into account that some authors,

\footnotetext{
6 See Marotti (2003: 52-79); Moulton (2000: 28); Smyth (2010: 99).

7 Beal (1980), Taylor (1985), Roberts (2003), among others. Moulton (2010) highlights the difficulty of determining who Margaret Bellasys was, as there were at least five separate women with that name in the early seventeenth century (p. 16).

8 See Roberts (2003: 181) for detailed information on the manuscript's transmission.

9 See Burke (2004) for an interesting contribution on four Folger Shakespeare Library MSS by female compilers.
} 
NEW WAYS OF LOOKING INTO HANDWRITTEN MISCELLANIES OF THE SEVENTEENTH CENTURY...

aware of the controversial nature of their texts, made sure their poems circulated anonymously. ${ }^{10}$ This would be the case with John Donne, for example, who held strict control over the circulation of his texts, especially those that could affect his reputation due to their risqué tone - his Elegies and Paradoxes - or their ideological stance - his Satires, Biathanatos, or Essays in Divinity. ${ }^{11}$ As Marotti (2006: 35) points out, Donne's poems did not reach a wide audience until the 1620s, when they were copied into manuscript anthologies by students from both universities.

The texts preserved in the different miscellanies from the period show signs of rewriting, which accounts for the significant variants in the texts they transmit. In the case of texts potentially controversial for their political or religious stance, this might go as far as to modify them so that they may adapt to changing contexts (Smyth 2006: 79). This would be the case, for example, with the libel on the Duke of Buckingham following his assassination in $1628,{ }^{12}$ or the popular poem "The Parliament Fart", ${ }^{13}$ that were adapted to agree with royalist agendas. ${ }^{14}$ Poems with opposite views on the same subject often come together, as would be the case with Spes Altera, that encourages marriage and procreation, and appears in the same manuscript as the anonymous poem whose first line reads: "Why should passion leade the blind" (fols 95v-96r). This poem has often been attributed to the Earl of Pembroke, famous for his reluctance to get married, ${ }^{15}$ and argues against the idea of haste in love matters, as it may cut off all hope of a fruitful autumn. It circulated in different miscellanies, among others in BL MS Add 30982, which also contains Sonnet 2, although with a different heading: "To one yt would dye a Mayd". This manuscript also adds a heading to Pembroke's poem: "On a made not marriagable" (fol. 19v), which is untitled in BL Add. MS 10309. The substantial differences between the versions in both manuscripts point to what was common practice among the compilers of these miscellanies, that of freely rewriting what came down to them, in line with their capacities and tastes. In the case of the

10 See Ezell (2015: 12); Love (2002: 205); Love (2013: 198).

11 See Marotti (2006) and Pebworth (2006). Both authors quote from Donne's letter to Sir Henry Wotton, asking him to restrict the circulation of the texts of the Paradoxes he was sending him: "to my satyrs there belongs some feare, and to some elegies, and these perhaps, shame" (Leicester Record Office, ff.308v-309, as cited in Pebworth 2006: 28). See also Marotti (2011: 74) on the tight control Donne held over the circulation of his Holy Sonnets.

12 See Smyth (2006: 78).

13 See Smyth (2010: 99); O'Callaghan (2006: 138.)

14 We share Smyth's (2006) views that "the reading of the politics of a collection, and the search for political consistency, is a delicate business" (75).

15 Jackson (2001), while discussing the efficacy of vocabulary evidence to date the Sonnets, suggests that Henry Herbert, earl of Pembroke would provide an acceptable chronological fit as the youth of Shakespeare's Sonnets, as he refused to marry Elizabeth Carey (1595-1596), Bridget Vere (1697), a niece of Charles Howard (1599), and Mary Fitton (1600-1601) (76). 
last poem mentioned, these differences affect its tone and style, and evince their compilers' different levels of literary competence.

The substantial differences between the handwritten and printed versions of Sonnet 2 similarly point to their authors' diverse approaches to its subject matter, together with their varying levels of literary competence.

\section{ASSESSMENT OF SPES ALTERA (B1) AS COMPARED TO SONNET 2 (Q)}

The comparison between Shakespeare's Sonnet 2, published by T. Thorpe in 1609, and the handwritten version contained in the British Library MS Add. MS 10309, here selected as the copy text for its accuracy, reveal a deliberate rewriting of the poem that is compatible with its author's connection with educated circles.

The manuscript version in no way can be deemed the result of careless or inattentive copying, as it shows a distinct and consistent pattern that tries to improve on what its author probably regarded as an inconsistent and faulty structure. At the same time, it evinces its author's meticulous attention to the poem's rhythm, which he carefully adapts to its logical pattern. Accordingly, he employs metrical inversions, such as the initial trochee in "Javes my account" (instead of the regular iambic pattern in Q "Shall sum my count"), in order to stress key words, in this case, the verb "fave", which is in the present instead of the future tense. This change highlights the lyric I's confidence that the young man's child will rescue him from destruction.

The MS also underlines the pride the young man will feel as a father, by having the stress fall on the adjective "pretty" in "If thou could ft fay this pretty childe of mine" (1.10), where $Q$ has "If thou could ft anfwere this faire child of mine". In order to do so, it replaces the bisyllabic "answere" in $\mathrm{Q}$ with the monosyllabic " Jay". This way, the stress no longer falls on "this" and "child" -leaving the adjective "faire" unstressed (Q)- but on "pretty".

At the structural level, a number of variants in MS reveal its author's wish to highlight the contrasting alternatives open to the youth at the devastating passage of time, which consist of either letting his beauty be buried by making a niggardly use of it, or letting it be born anew by bequeathing it unto his child. To this end, he rewrites "Thy youthes proud liuery $\int o$ gaz'd on now, / Wil be a totter'd weed of Jmal worth held" as "Thy youths faire Liu'rie foe accounted now / Shall be like rotten weeds, of no worth held" (11. 3-4). MS highlights the contrast between the youth's present splendour ("faire Liu'rie") and his eventual loss of it, by replacing Q's "totter'd" with "rotten", and Q's " mal worth" with "no worth". 
NEW WAYS OF LOOKING INTO HANDWRITTEN MISCELLANIES OF THE SEVENTEENTH CENTURY...

The variants in lines 6-8 can similarly be understood as their author's search for consistency in the development of a central idea, in this case, that of the youth's progressive loss of beauty, which in Q has additional overtones. Q's "Then being askt, where all thy beautie lies, / Where all the treafure of thy lufty daies; / To fay

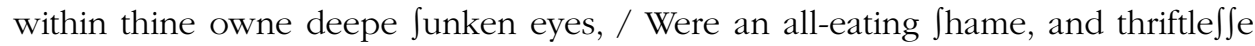
praife" is changed into: "Then being afk'd where all thy beautie lies / Where's all

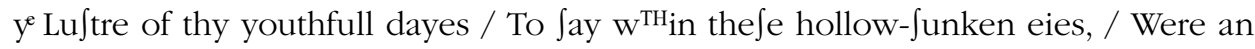
all-eaten truth, \& worthle $\iint e$ praife". The manuscript's "y e Luftre of thy youthfull dayes" (1. 6) develops the idea of youthful beauty started in line 1 ("louely feild"), continued in 1. 3 ("faire Liu'rie"), and contrasted with its presumed disappearance

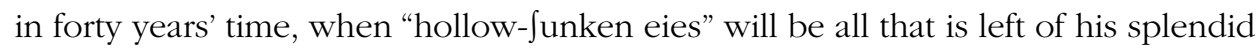
beauty and bright eyes ("Luftre"). Q does not sustain the idea of the loss of beauty as consistently as MS does. Instead, it refers to the youth's livery as "proud", and does not allude to the loss of youthful beauty in terms of its splendour, but of its "lusty" (with the obvious connotations of lustful) "treasure". The ironic allusion to the youth's "Sunken eyes", which can be related to the excesses of his youth, lead naturally to the all-eating shame he experiences when asked about the use he has put his beauty to. The MS version, conversely, pursues its logical argument to the end. That is why it replaces "all-eating Jhame" with "all-eaten truth", as a way of stating that it makes no sense to affirm that the youth's beauty lies in his hollow eyes. At the same time it prefers the adjective "worthle $\iint \mathrm{e}$ " over "thriftle $\iint \mathrm{e}$ " to qualify the noun "praife", probably because "worthle $\iint e$ praife" in line 8 echoes "of no worth held", from line 4.

MS pays careful attention to the relative position of words within the different lines of the poem. That is why, in the previous example, both "no worth" and "worthle $\iint \mathrm{e}$ " were located at the end of their respective lines. Similarly, the repetition of two words with the same root, "makes", "making", in lines 11 and 12, intensifies their relationship, so that "makes my old excuse" directly connects with "making his beautie by succe $\iint i o n$ thine", where Q has "proouing".

The contrast the final lines of the poem offer between the poet's imagined old age and the renewal he may experience if he fathers a child, is more marked in MS than Q, as MS has "new borne" where Q has "new made", thus establishing a sharper contrast between "new borne" and "old". This substitution has probably been prompted by its greater closeness to "warme blood" in the following line, that occupies the same position as "new born", and contrasts with "cold".

Having stated the importance the author of MS attaches to repetitions as a structuring feature of the poem, it is difficult to agree with Taylor's contention that the repetitions that fulfil this function in Q are absent from MS (1985: 241), for two out of the three instances he mentions of the repetition of "thy beautie" 
are identical in both texts (11. 5 and 9). There is just one case in MS where Q "thy beauties field" (1.2) has been replaced with "that louely feild", which has the advantage over $\mathrm{Q}$ of employing the deictic "that" that increases its sense of immediacy.

\section{CONCLUSION}

The analysis of the variant readings of Spes Altera (British Library, Add. MS 10309, f.143r) alongside the text of the 1609 printed edition of Shakespeare's Sonnet 2 suggests that the text was consciously rewritten during the first third of the Seventeenth century by an educated adapter who tried to improve on the sonnet's inner structure, imagery and rhythm. This conclusion differs from previous approaches to the manuscript version, that, taking into account stylometric findings, regarded it as a Seventeenth century transcription of an early draft of Shakespeare's sonnet, and, accordingly, deemed it stylistically inferior to the 1609 printed text. Taking into account the inconclusive nature of the stylometric analyses that related the rare words in the MS version to Shakespeare's early works, we have, instead, paid close attention to the text's context of production and reception, where we have found similar instances of conscious rewriting of literary texts with an educated readership in mind.

\section{REFERENCES}

Beal, P. 1980. Index of Literary Manuscripts. Vol. 1, Part 2. London: Mansell.

Burke, V. E. 2004. "Reading Friends: Women's Participation in 'Masculine' Literary Culture”. Early Modern Women's Manuscript Writing: Selected Papers from the Trinity / Trent Colloquium. Eds. V. E. Burke and J. Gibson. Aldershot: Ashgate. 75-90.

Burrow, C. 2007. "Editing the Sonnets". A Companion to Shakespeare's Sonnets. Ed. M. Schoenfeldt. Oxford: Blackwell. 145-162

Crowley, L. M. 2018. Manuscript Matters: Reading John Donne's Poetry and Prose in Early Modern England. Oxford: Oxford University Press.

Early English Books Online. 2003-2019. Ann Arbor, Michigan, MI: ProQuest, LLC.

Ennis, L. 1941. "Margaret Bellasys' 'Characterismes of Vices”. PMLA 56 (1): 141-150.

Ezell, M. J. M. 2015. "Handwriting and the Book". The Cambridge Companion to the History of the Book. Eds. L. Howsam and M. J. M. Ezell. Cambridge: Cambridge University Press. 90-106.

Henderson, J. R. 2007. "Humanism and the Humanities: Erasmus's Opus de Conscribendis Epistolis in Sixteenth-Century Schools". Letter-Writing Manuals 
NEW WAYS OF LOOKING INTO HANDWRITTEN MISCELLANIES OF THE SEVENTEENTH CENTURY...

and Instruction from Antiquity to the Present. Eds. C. Poster and L. C. Mitchell. Columbia, SC: The University of South Carolina Press. 141-177.

Jackson, M. P. 2001. "Vocabulary and Chronology: The Case of Shakespeare's Sonnets". Review of English Studies, 205: 59-75.

Love, H. 2013. "The Manuscript after the Coming of Print". The Book. A Global History. Eds. M. F. Suarez, S.J. and H.R. Woudhuysen. Oxford: Oxford University Press.197-204.

Marotti, A. F. 2006. "The Social Context and Nature of Donne's Writing: Occasional Verse and Letters". The Cambridge Companion to John Donne. Ed. A. Guibbory. Cambridge: Cambridge University Press. 35-48.

Marotti, A. F. 2007. "Shakespeare's Sonnets and the Manuscript Circulation of Texts in Early Modern England". A Companion to Shakespeare's Sonnets. Ed. M. Schoenfeldt. Oxford: Blackwell. 204-223.

Marotti, A. F. and M. Freiman. 2011. "The English Sonnet in Manuscript, Print and Mass Media". The Cambridge Companion to the Sonnet. Eds. A. D. Cousins and P. Howarth. Cambridge: Cambridge University Press. 66-83.

Marotti, A. F. 2016a. "Christ Church, Oxford, and Beyond: Folger MS V.a.345 and Its Manuscript and Print Sources”. Studies in Philology 113 (4): 850-878.

Marotti, A. F. 2016b. "The Circulation of Verse at the Inns of Court and in London in Early Stuart England". Re-evaluating the Literary Coterie, 1580-1830. Eds. W. Bowers and H. L. Crummé. Houndmills, Basingstoke: Palgrave Macmillan. 53-73.

Moulton, I. F. 2000. Before Pornography: Erotic Writing in Early Modern England. New York and Oxford: Oxford University Press.

O'Callaghan, M. 2006. "Performing Politics: The Circulation of the Parliament Fart". Huntington Library Quarterly 69: 121-138.

Pebworth, T. L. 2006. "The Text of Donne's Writings”. The Cambridge Companion to John Donne. Ed. A. Guibbory. Cambridge: Cambridge University Press. 23-34.

Roberts, S. 2003. Reading Shakespeare's Poems in Early Modern England. Basingstoke: Palgrave Macmillan.

Schoenfeldt, M. 2007. "The Sonnets". The Cambridge Companion to Shakespeare's Poetry. Ed. P. Cheney. Cambridge: Cambridge University Press. 125-143.

Schoenfeldt, M., eds. 2007. A Companion to Shakespeare's Sonnets. Oxford: Blackwell.

Shakespeare, W. 1609. Shake-speares sonnets Neuer before imprinted. Ed. T. T[horpe]. London: William Aspley. 
Shakespeare, W. 1985. Shakespeare's Sonnets and A Lover's Complaint. Ed. S. Wells. Oxford: Oxford University Press. (Original work published in 1609)

Shakespeare, W. 1997. The Norton Shakespeare. Based on the Oxford Edition. Eds. S. Greenblatt, W. Cohen, J. E. Howard and K. Eisaman Maus. New York, NY and London: W.W. Norton. (Original work published in 1623)

Shakespeare, W. 1999 (1986). The Sonnets and A Lover's Complaint. Ed. J. Kerrigan. New York, NY: Viking Penguin. (Original work published in 1609)

Shakespeare, W. 2002 (1997). Shakespeare's Sonnets. Ed. K. Duncan Jones. London Thomson Learning. (Original work published in 1609)

Shakespeare, W. 2002. William Shakespeare. The Complete Sonnets and Poems. Ed. C. Burrow. Oxford: Oxford University Press. (Original work published in 1609)

Shakespeare, W. 2006 (1996). The Sonnets. Ed. G. Blakemore Evans. The New Cambridge Shakespeare (updated ed.). Cambridge: Cambridge University Press. (Original work published in 1609)

Shakespeare, W. 2006 (2004). Shakespeare's Sonnets and Poems. Eds. B. A. Mowat and P. Werstine. New York, N Y: Washington Square Press. (Original work published in 1609)

Shakespeare, W. 2007. The RSC Shakespeare. William Shakespeare. Complete Works. Eds. J. Bate and E. Rasmussen. Houndmills, Basingstoke: Macmillan. (Original work published in 1623)

Shakespeare, W. 2016. The New Oxford Shakespeare. The Complete Works. Modern Critical Edition. Eds. G. Taylor, J. Jowett, T. Bourus and G. Egan. Oxford: Oxford University Press. (Original work published in 1623)

Shakespeare, W. 2017. The New Oxford Shakespeare. The Complete Works. Critical Reference Edition. Vol. 1. Eds. G. Taylor, J. Jowett, T. Bourus and G. Egan. Oxford: Oxford University Press. (Original work published in 1623)

Smyth, A. 2006. "Reade in one age and understood i'th'next': Recycling Satire in the Mid-Seventeenth Century". Huntington Library Quarterly 69 (1): 67-82.

Smyth, A. 2010. "Commonplace Book Culture: Sixteen Traits". Women and Writing, c. 1340-c.1650: The Domestication of Print Culture. Eds. A. L. Mathers and P. Hardman. Woodbridge: Boydell and Brewer. 90-110.

Taylor, G. 1985. "Some Manuscripts of Shakespeare's Sonnets". Bulletin of the John Rylands Library, 68: 210-246.

Virgil. 1620. Eclogues, with bis booke De apibus, concerning the gouernment and ordering of bees, translated grammatically, and also according to the proprietie of our English tongue, so farre as grammar and the verse will well permit. Written chiefly for the good schooles, to be vsed according to the directions in 
the preface to the painfull schoole maister, and more fully in the booke called Ludus literarius, or the grammar-schoole. Ludus literarius. Trans. J. Brinsley Ch. 8. London: Richard Field (2nd ed). (Original work published 37 BC)

Wells, S., Taylor, G., Jowett, J. and W. Montgomery. 1997. William Shakespeare. A textual Companion. New York, NY and London: W.W. Norton (1987. Oxford University Press).

Wilson, T., trans. 1553. "An Epistle to Persuade a Yong Iengleman to Marriage, Deuised by Erasmus in the Behalfe of his Frende". The arte of rhetorique for the vse of all suche as are studious of eloquence, sette forth in English, by Thomas Wilson. London: Richardus Graftonus.

Wilson, T. 1993. The Art of Rhetoric (1560). Edited with notes and commentary by Peter E. Medine. University Park, PA: Pennsylvania State University Press. 